\title{
The Meaning of Playing among Beggars Who Have Young Children
}

\author{
Nuzulul Pawestri ${ }^{1, *}$, Euis Kurniati ${ }^{2}$ \\ ${ }^{1,2}$ Department of Early Childhood Education, School of Postgraduate, Universitas Pendidikan Indonesia. \\ *Corresponding author. Email: nuzululpawestri@upi.edu
}

\begin{abstract}
Children's world is about playing. They spend most of their playing time. Playing benefits children in numerous aspects, i.e., it will develop competencies and creativity as they can learn with enjoyment. Therefore, playing is vital to children's growth. Unfortunately, not all parents can see this. One instance being parents who adopt beggar. Hence, this research focuses on the meaning of parents adopting beggar on playing activities for early childhood. The researcher used a qualitative approach with case study design, interview as means of data collection, and grounded theory for analysis. The results are expected to provide information on the importance of playing activities for beggar practitioner families and also input in the interest of protection and fulfillment of children's rights to play to achieve welfare.
\end{abstract}

Keywords: The meaning of beggar parents, playing in early childhood.

\section{INTRODUCTION}

Playing is a medium for children to learn to recognize the environment and is the most important and basic need for children, especially for early childhood [1]. Playing can be said as an activity that is done in a fun way and to get pleasure [2]. Meanwhile, according to early childhood education experts, playing is an effort performed by children to enter their fantasy world by doing the desired activities, so that they gain their own satisfaction.

Playing can be said as a release from the pressures faced by children [3]. Therefore, playing is a right that must be obtained by all children, in which it is an activity that is closely related to their world. Based on Article 11 in Law Number 23 of 2002 concerning Child Protection, it states that every child has the right to take a rest and advantage of their free time, socialize with peers, play, recreation, and create in accordance with their interests, talents and intelligence level for selfdevelopment [4].

Basically, children are able carry out various activities that can be used to learn something, recognize rules, socialize, place themselves, organize emotions, tolerance, cooperate, and uphold sportsmanship through playing. This is in line with the opinion stated by Vygotsky in Musfiroh [6] that children do not necessarily master knowledge due to maturity factors, but because of active interaction with their environment through playing [5].

In childhood, playing is the basis for their development because it is a part of development as well as a source of energy for the development itself [6]. The fun playing experiences with materials, objects, other children, and adult support help children develop optimally [7]. Parents provide freedom and stimulation for children to choose their own games and playmates. Giving stimulation to children is a task for adults, especially parents because they are the first educators for children [8]. No matter how small the participation performed by parents will affect the children's life, as well as the participation of parents in children's playing activities will affect the children's future development.

However, the importance of playing in children can be viewed differently by various parties including parents, considering that not all parents have the same understanding. There are several opinions of parents about playing activities in children who state that playing is a physical exercise and pleasure [9]. Harkness and Super argue that playing is an activity that is only done by children to get information [10]. There is also an opinion of parents who state that playing activities is a learning process to face life [11].

This was a case study research on the beggar community along the Gumitir mountain road, JemberBanyuwangi, with beggar practitioner parents as the 
respondents. Beggar activity referred to an activity commonly done by the beggar community to earn income by begging along the way with outstretched hands and there were some parents involving their children.

Therefore, this research intended to determine the meaning of beggar practitioner parents about playing activities in early childhood. Moreover, similar research has not been found in the area. The results of this research are expected to provide information and understanding of the importance of playing activities for the beggar families and can provide input for the protection and fulfillment of children's rights so that children's welfare can be achieved in that environment.

\section{THEORETICAL REVIEW}

\subsection{The Important of Playing for Early Childhood.}

Playing is an important activity for the growth and social development of children's emotional, cognitive, physical motoric to spiritual. Playing can be said to be a learning activity for early childhood because it is done without coercion and does not see the final result. By playing, children get new skills and have a function for their growth and development [12].

Through playing, children can have the skills to solve problems in various ways which are chosen according to the situation [13]. In addition, playing will increase children's vocabulary and their social development will develop because in this case they will learn to understand other people around them and collaborate with their friends. Playing is an activity that can provide experiences for children to socialize with others, expand their language vocabulary, as well as to help children expressing depressed feelings and reduce the sense of trauma or conflict they experience [14].

When children play with their friends, they will exchange thoughts and experiences they have. Thus, the egocentric nature of the child will be reduced. Playing activities in children can reduce their egocentric nature and they will like sharing with their friends [15].

\subsection{Parent's Meaning about Playing in Children}

Playing with children is a fun educational activity. Whereas, there are some parents who assume that only by studying, a child can be smart [16]. Furthermore, there are several notions about playing activity in children. Playing activity is a universal tool and every culture has sociality as well as becoming a provision in the future [17]. Parents' belief toward the existing culture can influence the children's playing activity [10].
Therefore, parents' meaning about the children's playing activity may be different due to their background, for example, the difference of parent's economical and educational backgrounds. If children do not have playing activity, it is the same as having no educational activity [9].

\subsection{Ecology Theory in Parenting}

This research employed Ecology theory of Urie Bronfenbrenner, in which in understanding a phenomenon, many wide factors are needed. The position of parenting in children's life can be obviously seen within the meaning of ecology. It is because ecology is a system in the closest environment or children's micro-system [18], [19].

The existing parenting program seems that the family lives in a vacuum without paying attention to other factors that contribute to parenting [20]. This makes ecology theory look at the parenting process by analysing external factors that can influence family understanding in supporting child development [18]. Ecology theory has been used to develop the parenting model which mentions that parenting behaviour is shaped based on the parent's and children's characteristics and also the social aspect [21].

Bronfenbrenner looked for the difference of parenting based on the social economic class and environmental ecological factors [18]. As stated by Fontes [22] about parenting and culture "child rearing is highly influenced by ethnic culture. What children need to learn and the methods considered best for teaching them are passed down from one generation to another as cultural knowledge" [22]. Accordingly, it can be concluded that the practice of parenting is the result of the existing culture and then the parenting method, which is inherited from one generation to the other, is given to the children. Therefore, the cultural aspect should be given attention in order to understand the phenomena of parenting given to the children.

\section{METHOD}

This research employed a qualitative approach with a case study design. Qualitative research aimed at analysing objects, social phenomena, and individual or group's perception naturally in which the researcher is the key instrument [23].

Meanwhile, the research method of case study was chosen because this research was intended to analyse the perception of beggar practitioner parents about playing activity in early childhood. Case study research explained some various aspects of individual, organizational, program as well as social condition in a comprehensive manner [24]. Qualitative approach with 
the case study method in this research was used to collect a deep meaning from a unique phenomenon [25].

The data collection technique in this study was an interview which aimed to obtain in-depth information about the phenomenon to be explored so that it can reveal the thoughts and feelings of the respondents [26]. The interview activity was conducted directly to the research respondents. The respondents in this study consisted of 3 families beggar along the Gumitir mountain road having early childhood at home. The first respondent was KP, 34 years old, who has three children. The second respondent, HA, is 32 years old with two children, and the last respondent is BP, 28 years old, who also has two children.

The data analysis used was grounded theory analysis. This analysis is a set of procedures used to construct a theory that describes a process regarding a substantive topic [27]. This research emphasized the meaning of playing among the beggar families. The choice of this method was based on the researcher's curiosity to analyse more deeply about the meaning of playing according to parents adopting beggar.

\section{FINDINGS AND DISCUSSION}

\subsection{Cultural-Based parenting}

The results of the interview conducted with both KP and HA revealed that playing activities for children was not needed because when children were allowed to play, the parents did not know what the children were doing so that there was no benefit. It is different when children are involved in beggar along the Gumitir mountain road where they will earn more income. This opinion is contrary to the experts who state that playing activities can affect six aspects of children's development which include self-awareness (personal awareness), emotional, social, communication, cognition, and motor skills [28]. The second respondent, HA, agreed with KP that playing was not necessary and had no effect on children's development. The following are some excerpts from the interviews with the two respondents:

Hahaha (laughing), why are children given the opportunity to play? If children are allowed to play, it will be even more troublesome. There is no benefit. They might fight with their friends later. Better to follow my husband and me. I leave early morning until evening and get money. In the past, I was also invited by my parents and I didn't have time to play with my peers. But there was no problem even if I didn't play. The most important thing is that it can meet the needs of the family (KP, Respondent 1).

Currently, the price of necessities is getting more expensive. If children are allowed to play later, they can be spoiled and waste time. Even if children are not allowed to play, it will not affect their life. The important thing is to always have an income every day. If I bring my children my income will increase. Even though my children often ask permission to play with their friends, I still don't allow them. When I was the same age as my children, I also went out with my parents every day. So, it has become commonplace in my family (HA, Respondent 2).

Based on interviews with $\mathrm{KP}$ and HA regarding the economic factor and activities carried out from generation to generation, KP and HA were motivated to involve their children in beggar along the Gumitir mountain road. Besides, KP and HA did not understand the importance of playing activities for early childhood. KP stated that since childhood, she was also involved by his parents in beggar so that the activities carried out by $\mathrm{KP}$ and HA's families have been passed down from generation to generation. This is in line with Fontes [22] who states that childcare activities are the result of an existing culture, which is then given to children and passed down from generation to generation.

On the contrary, according to the third respondent, $\mathrm{BP}$, playing activities for children is necessary so that $\mathrm{BP}$ allows the children to play. According to BP, if children are allowed to play, they are not addicted to watching TV or playing with gadgets. This explanation was revealed by BP in the interview as described below:

I think playing, for children, is a necessity. If children are not allowed to play, they are likely irritable, maybe because they are bored, right? If my children are not allowed to play, they are likely to be addicted to cell phones and TVs. Usually, if my children are allowed to play with their friends; I allow them to play as long as it is not dangerous. Sometimes I accompany the children to play the games that I used to play. And I try not to involve children in beggar because as a child I was also not allowed to join my parents on the grounds. After all, it was dangerous. Now I am trying to do the same so that later my children will not be like me, and I want my children to be able to continue their education at least like me, to graduate from high school (BP, Respondent 3).

Usually, the two BP children play jumping and climbing trees and cliffs not far from the BP location. BP also taught traditional games with easy materials that BP had played as a child. This was done by BP because she was never involved in beggar as a child. The opinion of BP about the importance of playing activities for children is supported by Brewer [29] who states that children need the opportunity to climb, swing, push, pull, run, jump, jump and walk to control their body [29]. Based on the results of the interview with the three respondents regarding the pattern of hereditary care activities, the involvement of children in begging is seen from the care that is applied to the 
children's parents. This is following what Fontes states that childcare activities are the result of the existing culture and then the method of care is given to children, where this parenting method is passed down from generation to generation [22]. Besides, Urie Bronfenbrenner's ecological theory also states that parenting activities can also be influenced by environmental factors [18].

\subsection{Fulfilling the Rights of Children in the Beggar Families}

Based on the results of the interview with BP regarding the meaning of playing for parents adopting beggar, BP stated that playing for children is an activity that must be carried out by all children without any restrictions as long as the activities carried out are safe and good for them. BP did not want her children to be involved in beggar. For BP, the children's duty and obligation are only to play and learn. This is in line with Presidential Decree No. 36/1990 concerning the Ratification of the Convention on the Rights of the Child, which contains 10 children's rights that must be fulfilled and one of them is playing [1]. The following is an excerpt from the interview with BP:

For children, playing is also a necessity. Moreover, I am not worried when my children go to school. Actually, in my opinion, the obligations of early childhood are only to play and learn. If the child comes with me to beg, I will worry more (BP Respondent 3).

However, in contrast to the opinion of $\mathrm{BP}$ (respondent 3), KP said that playing activities for children was a waste of time and had no benefit. KP preferred to involve his children in beggar every day from morning to evening. KP said when she involved her children in beggar, the income she earned was more. Furthermore, HA said that playing activities could harm her children when they were allowed to play. The following are excerpts from interviews with KP and HA:

I prefer to take my children on the side of the road because if they play, they will forget the time and I am also tired of reminding them. So, no results are obtained from playing. Then, if there is a raid, my children and I immediately move away and hide. The people here are like that too. After the raid, they must have continued begging (KP, Respondent 1$)$.

If the children play and don't join me in doing begging, our income that day will decrease. They also fight with their friends. If my children come along, the income I get can be used to save money (HA, respondent 2).

Therefore, HA believed that playing could harm children and she preferred to involve her children in beggar as KP did. This is contrary to the rights of children as referred to in Article 65 of Law Number 39 of 1999 concerning Human Rights, that every child has the right to obtain protection from exploitation activities, child trafficking, as well as from various forms of abuse of narcotics, psychotropic substances and addictive other substances [30].

According to the views of the three parents beggar about playing activities for their children, the result shows that their understanding of the importance of playing activities for their children is still lacking. 2 parents preferred to involve their children in begging. When playing, children learn and can understand new things that are around them. Playing is a process for children to understand themselves, other people, and their environment. It can be said that playing is a fun activity and helps children to achieve all aspects of development. Playing activities in children are very useful to support aspects of their development [14].

Based on the results of the interview above, these children were disadvantaged because their rights were not fulfilled due to the economic factor and the educational background of their parents. Even though the local government often carries out raids on beggar, those parents beggar keep repeating the same thing. Apart from carrying out raids, local governments should increase child protection efforts through increasing awareness, knowledge, and capacity of the community as well as improving the quality of the environment that provides opportunities, support, and freedom for children.

\section{CONCLUSION}

Playing becomes an important activity for children. Playing leads them indirectly to explore their world. Based on the data from the interview results done with 3 beggar practitioner parents about playing activities for the children, it was found that they still had a lack of understanding about the importance of playing activities for children. There were parents who argued that playing wasted their time and brought up the disadvantages to them.

The economic and cultural factors affected the meaning of beggar practitioner parents about playing activities for children. In addition, the beggar practitioner parents expressed their lack of understanding on the importance of playing activities in children and their educational background.

The recommendation suggested in the further research is to provide the beggar practitioner parents an understanding on the importance of playing activities for children to support the development and growth and fulfil their rights. 


\section{ACKNOWLEDGMENTS}

We are thankful to all respondents who have shared their voices with us

\section{REFERENCES}

[1] Keputusan Presiden Republik Indonesia Nomor 36 Tahun 1990 Tentang Pengesahan Convention on The Rights of The Child (Konvensi Tentang HakHak Anak); 1990.

[2] Docket S, Fleer M. Play and pedagogy in early childhood: Bending the rules. Sidney: Harcourts Brace; 2000.

[3] Montolalu dkk. Bermain dan permainan anak. Jakarta: Universitas Terbuka; 2007.

[4] Undang-Undang Nomor 23 Tahun 2002 tentang Perlindungan Anak. 2002.

[5] Musfiroh T. Bermain sambil belajar dan mengasah kecerdasan. Jakarta. Depdiknas; 2005.

[6] Musfiroh T, Tatminingsih S. Bermain dan permainan anak. Tanggerang Selatan: Universitas Terbuka; 2015.

[7] Mutiah D. Psikologi bermain anak usia dini. Jakarta: Kencana; 2010.

[8] Noorlaila I. Panduan lengkap mengajar PAUD. Yogyakarta: Pinus Publisher; 2010.

[9] Singh A, Gupta D. Contexts of childhood and play: Exploring parental perceptions. Childhood. 2012 May;19(2):235-50. DOI: https://doi.org/10.1177/ 0907568211413941.

[10]Harkness S, Super CM. Introduction. In: Harkness $\mathrm{S}$ and Super CM, editors. Parents' Cultural Belief Systems. New York: Guilford Press; 1996.

[11]Lieberman JN. Playfulness: Its relationship to imagination and creativity. New York: Academic Press; 2014.

[12] Khasanah I, Prasetyo A, Rakhmawati E. Permainan tradisional sebagai media stimulasi aspek perkembangan anak usia dini. Jurnal Penelitian PAUDIA. 2011;1(1):91-105.

[13]Isbell RT. The Complete learning center book. Beltsville. Maryland: Gryphon House; 1995.

[14] Saputra T, Mayke S. Bermain, mainan dan permainan. Jakarta: Grasindo; 2001.

[15] Rohmah N. Bermain dan pemanfaatannya dalam perkembangan anak usia dini. Jurnal Tarbawi. 2016;13(2):28-35.

[16] Thobroni M, Mumtaz F. Mendongkrak kecerdasan anak melalui bermain dan permainan. Yogyakarta: Katahati; 2011.
[17] Opie P, Opie I. The lore and language of school children. Oxford: Oxford University Press; 1970.

[18]Bronfenbrenner U. The ecology of human development: Experiments by nature and design. Cambridge: Harvard University Press; 1979.

[19]Etikawati AI, Siregar JR, Widjaja H, Jatnika R. Mengembangkan konsep dan pengukuran pengasuhan dalam perspektif kontekstual budaya. Buletin Psikologi. 2019;27(1):1-4. Available from: https://doi.org/10.22146/buletinpsikologi.41079

[20]Brody GH, Flor DL. Linking maternal efficacy beliefs, develop-mental goals, parenting practices, and child competence. Child Development. 1999; 70(5):1197-208.

[21] Belsky J. The determinants of parenting: A process model. Child Development; 1984 Feb 1;55(1):8396.

[22] Fontes LA. Child discipline and physical abuse in immigrant Latino families. Journal of Counseling and Development; 2002 Jan;80(1):31-40.

[23] Sugiyono. Metode penelitian kuantitatif, kualitatif dan R\&D. Bandung: PT Alfabet; 2016.

[24] Mulyana D. Metode penelitian kualitatif. Bandung: PT. Remaja Rosdakarya; 2002.

[25]Creswell JW. Research design (Pendekatan Kualitatif, Kuantitatif dan Mixed) Edisi Revisi. Yogyakarta: Pustaka Pelajar; 2013.

[26]Lincoln, YS, Egon GG. Naturalistic inquiry. California: SAGE; 1985.

[27]Egan T, Marshall. Grounded theory research and theory building. Advances in Developing Human Resources. 2002;4(3):477-95.

[28] Catron CE, Allen J. Early childhood curriculum a creative-play model. New Jersey: Merill, PrenticeHall; 1999.

[29]Brewer JA. Introduction to early childhood education: Preschool through primary grades. Boston: Allyn and Bacon; 1995.

[30] Undang-Undang Nomor 39 Tahun 1999 tentang Hak Asasi Manusia; 1999. 